Sмiтн, W. K. (1958). J. gen. Microbiol. 18, 33-41

\title{
A Survey of the Production of Pectic Enzymes by Plant Pathogenic and other Bacteria
}

\author{
BY W. K. SMITH \\ Imperial Chemical Industries Ltd., Akers Research Laboratories, \\ Welwyn, Hertfordshire
}

SUMMARY : Sixty-seven cultures of plant pathogenic bacteria, of the genera Agro. bacterium, Corynebacterium, Erwinia, Pseudomonas and Xanthomonas, and 56 cultures of non-pathogenic bacteria were tested for production of pectic enzymes in culture. $\gamma$-Pectinglycosidase was produced by 22 strains of pathogenic bacteria and by 15 non-pathogens. Pectin methyl esterase was produced by a few pathogens: the soft-rot erwinias, $X$. campestris and one of three strains of $X$. vasculorum.

Bacteria of several genera are known to degrade pectic materials and, in fact, this ability can be used to distinguish Erwinia carotovora from the very similar non-phytopathogenic species Klebsiella aerogenes. There is, however, very little knowledge of the enzymic processes involved, of how the bacterial enzymes differ from similar plant or fungal enzymes or of the differences between the enzyme systems of pathogenic and non-pathogenic species. Some of the latter degrade pectin with great rapidity and yet are unable to cause a softrot of the living plant.

These questions should be resolved for a proper understanding of the disease processes and for the possible development of protective measures based on prevention of pectin breakdown. With this in mind bacteria of several genera have been tested for ability to produce pectic enzymes in vitro. The procedures used were designed to give some indication of the character of any pectic enzyme which might be observed.

Pectolytic activity in fungi, which have been studied more extensively than bacteria, has generally been found to depend upon a complex of enzymes which may include pectin methyl esterase (PME) and one or more of a group of glycosidases. The classification and nomenclature of the latter are somewhat confused: many can be fitted into the scheme outlined in Table 1, but this scheme should be regarded as illustrative rather than definitive until further work, with standardized methods, shows which characteristics are intrinsic to the various groups. The testing procedure adopted was planned on the framework of Table 1. Schubert's (1954) term pectin glycosidase (PG) is preferred.

\section{METHODS}

General procedure. The bacteria were grown in a complex medium containing pectin. Samples were withdrawn at intervals and tested for the presence of PME and PG and for the degradation of the pectin. To detect $\alpha-, \beta$ - and $\gamma-\mathrm{PG}$ substrates of high- and low-methoxyl pectin, at $\mathrm{pH}$ values of $3 \cdot 5,5.5$ and $7 \cdot 5$, 
with appropriate additions of $\mathrm{Ca}^{++}$and $\mathrm{NaCl}$ (see Table 2) were used. It was hoped that this range would also reveal any other pectic enzymes that might be produced, but, as a further test for unsuspected enzymes, destruction of the pectin in the culture was tested by the nature of the precipitate formed on adding ethanol.

\section{Table 1. Enzymes degrading pectic substances}

\begin{tabular}{|c|c|}
\hline $\begin{array}{l}\text { Names pro- } \\
\text { posed }\end{array}$ & $\begin{array}{l}\beta \text {-Pectinglycosidase } \\
(1), \beta \text {-polygalacturo- } \\
\text { nase or enzyme } I b(2)\end{array}$ \\
\hline pH optimum & c. $3 \cdot 5$ \\
\hline Substrate & $\begin{array}{l}\text { Pectic acid, low-ester } \\
\text { pectin, uronides pro- } \\
\text { duced by } \alpha \text {-PG and } \\
\gamma \text {-PG }\end{array}$ \\
\hline Products & $\begin{array}{l}\text { Mono-, di- and tri- } \\
\text { galacturonic acid (2) }\end{array}$ \\
\hline Effects of salts & $\begin{array}{l}\mathrm{NaCl} \text { contracts and } \\
\text { lowers optimum pH } \\
\text { range (1) }\end{array}$ \\
\hline $\begin{array}{l}\text { Similar } \\
\text { enzymes }\end{array}$ & $\begin{array}{l}\text { Penicillium expan- } \\
\text { sum oligase (4), } \\
\text { yeast PG (5) }\end{array}$ \\
\hline \multicolumn{2}{|c|}{$\begin{array}{l}\text { (1) Schubert (1954). } \\
\text { (2) Dingle, Reid \& Solomons (1953). } \\
\text { (3) Wood (1951). } \\
\text { (4) Ozawa (1951). }\end{array}$} \\
\hline
\end{tabular}

$\alpha$-Pectinglycosidase (1), $\gamma$-Pectinglycosidase (1) $\alpha$-polygalacturonase or enzyme I $a(2)$

c. $\mathbf{5} \cdot \mathbf{5}$

High methoxyl pectin; pectic acid slowly or not at all.(1)

Uronides not precipitated at $\mathrm{pH} 1 \cdot 0$, but not mono-, di-, trigalacturonic acid (2)

$\mathrm{NaCl}$ spreads and raises $\mathrm{Ca}^{++}$required for maxioptimum $\mathrm{pH}$ range (1) mum activity (3)

P. expansum polyase(4), Erwinia aroideae depopectin depolymerase lymerase (3), enzymes from Neurospora sp.(6) from Pseudomonas spp. polymethylgalacturo- $\quad(7)$ nase (8)

Uronides not precipitated by $66 \%$ ethanol High methoxyl pectin, pectic acid (3)

(5) Luh \& Phaff (1951).

(6) Roboz, Barratt \& Tatum (1952).

(7) Oxford (1944).

(8) Seegmiller \& Jansen (1952).

Table 2. Substrates for viscosimetric tests

\begin{tabular}{|c|c|c|c|c|c|c|}
\hline $\begin{array}{c}\text { Pectic } \\
\text { substance: }\end{array}$ & $\begin{array}{c}\text { Pectic } \\
\text { acid }\end{array}$ & Pectin & $\begin{array}{c}\text { Pectic } \\
\text { acid }\end{array}$ & Pectin & $\begin{array}{c}\text { Pectic } \\
\text { acid }\end{array}$ & Pectin \\
\hline \multirow{2}{*}{\multicolumn{2}{|c|}{$\begin{array}{l}\text { Concentration }(\%): 0.5 \\
\text { pH value: }\end{array}$}} & $0 \cdot 5$ & 0.5 & 0.5 & 0.5 & 0.625 \\
\hline & \multicolumn{2}{|c|}{$3 \cdot 5$} & \multicolumn{2}{|c|}{$5 \cdot 5$} & \multicolumn{2}{|c|}{$7 \cdot 5$} \\
\hline Buffer: & \multicolumn{2}{|c|}{ None } & \multicolumn{2}{|c|}{$0.01 \mathrm{M}$-succinate } & \multirow{2}{*}{\multicolumn{2}{|c|}{$\begin{array}{c}0.01 \mathrm{M}-\mathrm{ph} \text { osphate } \\
0.00125 \mathrm{M}\end{array}$}} \\
\hline $\mathrm{CaCl}_{2}$ : & \multicolumn{2}{|c|}{0} & \multicolumn{2}{|c|}{0} & & \\
\hline $\mathrm{NaCl}(\mathbf{M}):$ & $0 \cdot 2$ & $\mathbf{0}$ & 0.2 & $0 \cdot 2$ & \multicolumn{2}{|c|}{$0.2 \quad \begin{array}{ll}0.00125 M \\
0.2 & 0.2\end{array}$} \\
\hline Phenol (\%): & $0 \cdot 2$ & $0 \cdot 2$ & 0.2 & 0.2 & $0 \cdot 2$ & 0.25 \\
\hline
\end{tabular}

Of the many possible methods of detecting pectolysis of the various substrates, loss of viscosity was chosen because $(a)$ it is the most sensitive indicator of degradation of the pectic material, $(b)$ it probably reflects the changes significant in soft rotting, $(c)$ it can be measured easily and rapidly provided high accuracy is not required. To minimize the effects of substances other than pectic enzymes on the viscosity of the substrates the proportion of culture added was kept low $(0 \cdot 6 \mathrm{ml} .+7 \cdot 4 \mathrm{ml}$. substrate). This made an incubation period of $24 \mathrm{hr}$. necessary and an antiseptic had to be added to prevent microbial growth. Preliminary tests showed that phenol did not affect viscosity diminution by enzymes from Erwinia carotovora and $0.2 \%(\mathrm{w} / \mathrm{v})$ was incorporated in the substrates. 


\section{Pectic enzymes of bacteria}

Organisms. Stock cultures of bacteria, obtained from various sources, were maintained on 'Oxoid' Griffiths Egg-salt Medium (Oxo Ltd., 16 Southwark Bridge Road, London, S.E. 1) stored in the refrigerator after 3-4 days of growth. Designations used by the persons who supplied the cultures were accepted without checking. The nomenclature of Bergey's Manual (6th edition) has been used except with the Enterobacteriaceae where the recommendations of the Coli-Aerogenes (1956) Sub-Committee of the Society for Applied Bacteriology have been followed.

When required, subcultures from the egg-salt slopes were grown on slopes of nutrient agar for about 5 days and then transferred to tubes of IM 1 medium (see below) for 2 days before inoculating the flasks of SM 1 medium (see below) in which they were grown for the enzyme tests.

Media. IM 1 medium; Tryptone (Difco), 0.4\%; yeast extract (Difco), $0.01 \%$, glucose, $0 \cdot 1 \%$.

SM 1 medium-solution A; Brown Ribbon pectin, ${ }^{*} 5$ g.; glucose, 0.5 g.; in $500 \mathrm{ml}$. water at $\mathrm{pH} 6 \cdot 5-7 \cdot 0$. Solution B: Tryptone, $5 \mathrm{~g}$; yeast extract, 2.5 g.; $\left(\mathrm{NH}_{4}\right)_{2} \mathrm{HPO}_{4}, 2.5$ g.; L-asparagin (monohydrate), 1.0 g.; $\mathrm{Na}_{2} \mathrm{HPO}_{4}$, $0.05 \mathrm{~g}$., $\mathrm{K}_{2} \mathrm{HPO}_{4}, 0.05 \mathrm{~g}$. The asparagin was dissolved separately and added to the other components dissolved in $c .1 .5 \mathrm{l}$. of water. After the $\mathrm{pH}$ value had been adjusted to $6 \cdot 5-7 \cdot 0$ the volume was made up to 2 l. Solution A, in $25 \mathrm{ml}$. amounts and solution $\mathrm{B}$, in $100 \mathrm{ml}$. amounts, were autoclaved separately and mixed when cool.

Pectic substrates. For pectin methyl esterase test: Brown Ribbon pectin, 0.5 g.; phenol, 0.2 g.; NaCl, 0.58 g.; bromthymol blue solution (British Drug Houses Ltd., Poole, Dorset) $2.5 \mathrm{ml}$.; water, to $100 \mathrm{ml}$. Before use the colour of the indicator was adjusted to green by addition of $\mathrm{N}-\mathrm{NaOH}$. For viscosimetric tests: pectic acid was prepared from Brown Ribbon pectin by the method of Jermyn \& Tomkins (1950). Stock $1 \%(\mathrm{w} / \mathrm{v})$ solutions of pectin and pectic acid were used to prepare the substrates summarized in Table 2.

Preparation of culture solutions for testing. Conical flasks $(250 \mathrm{ml}$.) containing medium SM 1 (125 ml.) were inoculated with $1 \mathrm{ml}$. of $48 \mathrm{hr}$. cultures in medium IM 1 and incubated statically at $25^{\circ}$. At approximately weekly intervals samples were withdrawn and centrifuged at $1200 \mathrm{~g}$ for $15 \mathrm{~min}$.

\section{Tests on culture supernatant fluids}

$\mathrm{pH}$ values were measured by glass electrode.

Ethanol precipitation. Absolute ethanol (2 ml.) was added to $1 \mathrm{ml}$. of culture supernatant fluid, shaken and centrifuged; the sediment was compared with that from an uninoculated control and graded arbitrarily.

Pectin methyl esterase. A sample (0.6 ml.) of centrifuged culture was pipetted into each of two test tubes. One was immersed in a boiling-water bath for $10 \mathrm{~min}$. to inactivate the enzyme. Substrate $(7 \cdot 4 \mathrm{ml}$.) was added to each tube followed by dilute $\mathrm{NaOH}$ until the indicator was blue. The tubes were

* 'Brown Ribbon' pectin is a pharmaceutical grade pectin with $12.5 \%$ methoxyl (on weight of pectin) obtained from Union Crystalex Gelatine Ltd., Garrett Street, Golden Lane, London, E.C. 1. 
incubated for at least $24 \mathrm{hr}$. at $30^{\circ}$. The production of an acid reaction in the unheated tube was taken to indicate the presence of PME. The heated tube served as a control on non-enzymic acid production and as a colour standard.

Pectin glycosidase. Various substrates (Table 2) in $7 \cdot 4 \mathrm{ml}$. amounts were added to $0.6 \mathrm{ml}$. of culture supernatant and mixed. After mixing the tubes were incubated in a $30^{\circ}$ water bath for $24 \mathrm{hr}$. Viscosities were then measured by a simple pipette, similar to the Baker 'Jelmeter' (see Kertesz, 1951, p. 482), with a delivery tube of $1.6-1.7 \mathrm{~mm}$. internal diameter. In any set of readings a separate pipette was used for each substrate; after a measurement it was rinsed with boiling distilled water, drained and placed on an air line while readings were taken on the other five substrates, by which time it was sufficiently cool and dry to use again. Generally loss of viscosity was obvious, being practically complete with the more active cultures. Pectin glycosidase activity was only considered to be present when the decrease of viscosity was greater than $10 \%$ of the maximum possible.

\section{RESULTS}

Table 3. Species showing neither pectin glycosidase nor pectin methyl esterase activity.

(a) Plant pathogenic species

$\begin{array}{llll}\text { Agrobacterium radiobacter } & (1 / 1) & \text { P. mors-prunorum } & (\mathbf{4} / 4)^{*} \\ \text { A. rhizogenes } & (1 / 1) & \text { P. prunicola } & (1 / 1) \\ \text { A. tumefaciens } & (2 / 2) & \text { P. syringae } & (4 / 5) \\ \text { Corynebacterium fascians } & (2 / 2) & \text { P. tabaci } & (1 / 1) \\ \text { C. flaccumfaciens } & (1 / 1) & \text { Xanthomonas begoniae } & (\mathbf{2} / 2) \\ \text { C. michiganense } & (2 / 2) & X . \text { hyacinthi } & (3 / 3) \\ \text { Errvinia tracheiphila } & (1 / 1) & X . \text { juglandis } & (3 / 3) \\ \text { Pseudomonas coronafaciens } & (1 / 1) & X . \text { malvacearum } & (5 / 5) \\ \text { P. delphinii } & (1 / 1) & X . \text { phaseoli } & (1 / 1) \\ \text { P. marginalis } & (2 / 3) & X . \text { pruni } & (2 / 2) \\ \text { P. medicaginis } & (1 / 1) & X . \text { vasculorum } & (3 / 4) \\ \text { P. medicaginis var. phaseo- } & (1 / 3) & & \end{array}$

(b) Non-pathogenic species

\begin{tabular}{lccr} 
Serratia marcescens & $(1 / 1)$ & $\begin{array}{c}\text { Rhizobium sp. } \\
\text { (? meliloti) }\end{array}$ \\
Flavobacterium aquatile & $(1 / 1)$ & Proteus vulgaris & $(3 / 4)$ \\
F. devorans & $(1 / 1)$ & Pseudomonas aeruginosa $(1 / 1)$ \\
Klebsiella pneumoniae & $(1 / 1)$ & $\begin{array}{c}\text { Pseudomonas spp. from }(3 / 5) \\
\text { plant material }\end{array}$ \\
\multicolumn{2}{l}{ Coli-aerogenes bacteria } & $(26 / 32)$ & (see Table 6$)$ \\
* 3 of the strains of $P$. mors-prunorum gave positive results in single tests.
\end{tabular}

The results are summarized in Tables 3-6. The figures in parentheses $(a / b)$ refer to $(a)$ the number of strains showing the property listed, $(b)$ total number of strains of that species tested. 


\section{Table 4. Species showing pectin glycosidase activity but no pectin methyl esterase}

\begin{tabular}{llll} 
Erreinia carotovora & $(1 / 5)$ & P. medicaginis var. phaseolicola & $(2 / 3)$ \\
E. rhapontici & $(1 / 1)$ & P. syringae & $(1 / 5)$ \\
Pseudomonas marginalis & $(1 / 3)$ & Xanthomonas papavericola & $(1 / 1)$ \\
& \multicolumn{4}{c}{} \\
& $($ b) Non-pathogenic species & \\
Bacillus macerans & $(2 / 2)$ & Flavobacterium sp. from soil & $(1 / 1)$ \\
B. polymyxa & $(2 / 2)$ & Pseudomonas spp. from plant & $(2 / 5)$ \\
B. subtilis & $(\mathbf{2} / 2)$ & material & \\
Coli-aerogenes bacteria & $(6 / 32)$ & (see Table 6)
\end{tabular}

Table 5. Species showing both pectin glycosidase and pectin methyl esterase activity

(a) Plant pathogenic species

$\begin{array}{llll}\text { Erreinia aroideae } & (2 / 2) & \text { E. phytophthora } & (1 / 1) \\ \text { E. atroseptica } & (4 / 4) & \text { Xanthomonas campestris } & (3 / 3) \\ \text { E. carotovora } & (4 / 5) & X \text {. vasculorum } & (1 / 4)\end{array}$

(b) Non-pathogenic species

None

Table 6. Production of pectin glycosidase by various types of coli-aerogenes bacteria

\begin{tabular}{|c|c|c|c|c|}
\hline \multirow[b]{2}{*}{ Type } & \multicolumn{2}{|c|}{ No of strains } & \multicolumn{2}{|c|}{ Source of strains } \\
\hline & Tested & $\begin{array}{c}\text { P.G. } \\
\text { positive }\end{array}$ & Positive & Negative \\
\hline E. coli I and II & 6 & 0 & 一 & $\mathbf{M}, \mathbf{3} ; \mathbf{U}, \mathbf{3}$ \\
\hline Cit. freundii I and II & 11 & 1 & $\mathbf{W}, \mathbf{I}$ & $\mathrm{M}, 3 ; \mathrm{S}, 3 ; \mathrm{W}, \mathbf{2} ; \mathrm{U}, \mathbf{2}$ \\
\hline $\boldsymbol{K}$. aerogenes I and II & $\mathbf{9}$ & 4 & $\mathrm{~S}, \mathbf{3} ; \mathrm{W}, \mathbf{1}$ & $\mathrm{M}, 1 ; \mathrm{S}, 1 ; \mathrm{W}, 2 ; \mathrm{U}, \mathbf{1}$ \\
\hline K. cloacae & 4 & $\mathbf{1}$ & $\mathbf{W}, \mathbf{1}$ & $M, 1 ; S, 1 ; W, 1$ \\
\hline Irregular & 1 & $\mathbf{0}$ & - & $\mathbf{U}, \mathbf{1}$ \\
\hline Paracolon & 1 & $\mathbf{0}$ & - & $\mathrm{U}, \mathbf{1}$ \\
\hline
\end{tabular}

* Sources; M, milk; S, soil; W, water; U, unknown.

\section{DISCUSSION}

The occurrence of pectin glycosidase in the bacterial species studied in this investigation is more or less in accord with previous reports. More striking is the restricted distribution of pectin methyl esterase.

Turning first to pectin glycosidase and the various genera in which it was found, it should be noted that the pectolytic activity was of the $\gamma$-PG type; i.e. destruction of viscosity was more rapid at $\mathrm{pH} 7.5$ than at $\mathrm{pH} 5.5$ or 3.5 and both pectin and pectic acid were attacked. In a few instances the activities at $\mathrm{pH} 5.5$ were sufficiently high to suggest that $\alpha-\mathrm{PG}$ might also be present but this always accompanied very high activity at $\mathrm{pH} 7 \cdot \mathbf{5}$. The present evidence is insufficient to state definitely whether $\alpha-P G$ was or was not present in these cases. It is worth noting that Kraght \& Starr (1953) found that an 
enzyme from Erwinia carotovora had an optimum $\mathrm{pH}$ of about 5.8 for the liberation of reducing groups from pectic acid, whilst Ozawa (1947) found an optimum of 5.5-6.0 for the 'protopectinase' of $E$. aroideae. Most of the cultures in which the presence of $\alpha-P G$ was suspected in this investigation were of the soft-rot erwinias.

Bacillus species. All three species tested, and found to produce PG havc been reported to be active against pectic materials (Allen, 1944; Jacobelli, 1953; McCready, Owens \& Maclay, 1943; Nortje \& Vaughn, 1953; Ozawa, 1947; Rudd Jones, 1946), although some of these authors used gel liquefaction techniques which did not give unequivocal evidence of enzyme production or indicate the properties of any enzyme concerned. Ozawa (1947) found a $\mathrm{pH}$ optimum of 8-9 for the 'protopectinase' of Bacillus natto $(=B$. subtilis) and Nortje \& Vaughn (1953) give $8 \cdot 6$ as the optimum for the pickle-softening enzyme of $B$. subtilis.

Pseudomonas species. The chief characteristic of pectic enzyme production in Pseudomonas seems to be its variability: the three positive species $P$. marginalis, $\boldsymbol{P}$. phaseolicola, $\boldsymbol{P}$. syringae each included inactive strains. The results of Oxford (1944) also suggest variation between strains of Pseudomonas spp. particularly when it is noted that Mills (1949) found PME (and so, probably, PG) to be produced by $\boldsymbol{P}$. prunicola, which Oxford reported as not pectolytic (2 strains) and which also gave negative results in the present investigation, as did P. tabaci which Oxford and Sabet \& Dowson (1951) found to be pectolytic. None of the saprophytes tested by Oxford were pectolytic but two of the strains used in the present investigation produced PG. This variability may be inherent in the species tested or some strains may have lost the faculty during laboratory cultivation; before accepting pectolytic ability as a diagnostic feature in this genus it would be necessary to make certain that the former was not the case and to prevent the latter as far as possible.

Xanthomonas species. Although this genus does not, apparently, possess pectolytic activity as a general attribute, it includes the only species, outside the soft-rot erwinias, found to produce pectin methyl esterase, viz. all three strains of Xanthomonas campestris and one strain of $\boldsymbol{X}$. vasculorum. These two species and $X$. papavericola, the other producer of PG, are related serologically while the remaining species tested fall into other serological groups (Elrod \& Braun, 1947). According to Sabet \& Dowson (1951) X. begoniae and X. malvacearum (both negative in this investigation) caused 'slight, thick liquefaction' of their pectate gel medium, but this cannot be regarded as definite evidence of the production of pectic enzymes; $X$. citri (not tested here) and $X$. campestris $(\mathbf{P G}+, \mathrm{PME}+)$ caused 'moderate liquefaction and clear liquid'. Shishelova (1951) found that $X$. campestris produced 'protopectinase' in vitro and in vivo; two other species, $X$. phaseoli and $X$. translucens produced it only in infected plants.

Agrobacterium and Corynebacterium species. No evidence of pectic enzyme production was found in these two genera, although Sabet \& Dowson (1951) reported 'slight to moderate liquefaction' for Agrobacterium tumefaciens. According to Shishelova (1951) Corynebacterium michiganense did not produce 
protopectinase in vivo or in vitro. The nature of the diseases caused by these pathogens does not suggest that pectic degradation is involved.

Coli-aerogenes bacteria. The relationship between the soft-rot erwinias and the coli-aerogenes group of bacteria has been debated for some time (Stuart, Griffin \& Baker, 1938; Stuart et al. 1940; Elrod, 1942; Taylor, 1951). Taylor found that of 19 soft-rot bacteria akin to Erwinia carotovora, 17 liquefied pectate gel whilst none of some 300 other coli-aerogenes bacteria did so. So far, however, the enzymes involved in gel liquefaction have not been identified or the possibility of non-enzymic softening excluded. Some caution is therefore necessary in applying this as a diagnostic test, although the method is undoubtedly valuable for isolating or enumerating potentially pectolytic organisms (Wieringa, 1949; Elis Jones, 1956). It is noteworthy that all six PG-producing coliform organisms were isolated from soil or water and that 5 of them were of the aerogenes-cloacae type most closely related to $E$. carotovora.

Pectin methyl esterase was more restricted in its distribution than pectin glycosidase and was never found in the absence of the glycosidase. Although Pseudomonas prunicola showed neither PG nor PME in this investigation Mills (1949) found it to be an active producer of the esterase when grown in the presence of pectic material. Fabian \& Johnson (1938) claimed to have demonstrated that members of the Bacillus mesentericus-megaterium group produced pectase $(=\mathrm{PME})$ and protopectinase but not pectinase $(=\mathrm{PG})$ but gave no experimental details of their methods or results. Kraght \& Starr (1953) showed production of PME by five strains of Erwinia carotovora, but Wood (1955) concluded that his culture of $E$. aroideae was essentially free from PME. During the present investigation it has been observed that formation of PME is much more sensitive to variations in the cultural conditions than is PG formation. The fact that Wood used a simple medium containing no pectic material probably explains the absence of PME from his culture solutions. Whilst the study of an individual enzyme is facilitated by the use of a medium selective for its production the whole pectolytic complex must be kept in view when the disease processes are being considered. Nutrient conditions in the infection count are far from simple and pectic substances are almost certainly present in forms which will induce adaptive enzyme formation. Production of PME seems likely and its role in soft-rotting is discussed in an accompanying paper (Smith, 1958).

In summary it can be said that a number of saprophytic bacteria as well as some plant pathogenic species produce enzymes which degrade pectic substances but production of PME is confined to a small number of pathogens. These are the soft-rot Erwinia spp. and Xanthomonas campestris, in each of which it might well be a diagnostic feature, and $X$. vasculorum, where the faculty is less constant.

I am grateful to Dr Jean Malcolmson, Dr J. Kleczkowski, Dr A. Paton, Dr S. B. Thomas, Dr W. J. Dowson, Dr J. E. Crosse, Dr D. H. Lapwood, Dr G. M. Wickens, The National Collection of Industrial Bacteria and the National Collection of Plant Pathogenic Bacteria for providing cultures and to Mrs P. B. Coomber and Mr G. F. Richmond for technical assistance. 


\section{REFERENCES}

Allen, L. A. (1944). Spore-forming bacteria causing soft rot of potato and retting of flax. Nature, Lond. 153, 224.

Bergey's Manual of Determinative Bacteriology, (1948). 6th ed. Edited by Breed, R. S., Murray, E. G. D. \& Hrtchens, A. P. London: Ballière, Tindall and Cox.

Dingle, J., Reid, W. W. \& Solomons, G. L. (1953). The enzymic degradation of pectin and other polysaccharides. II. Application of 'cup-plate' assay to the estimation of enzymes. J. Sci. Fd Agric. 4, 149.

Elrod, R. P. (1942). The Erwinia-coliform relationship. J. Bact. 44, 433.

Elrod, R. P. \& Braun, A. C. (1947). Serological studies of the genus Xanthomonas. I. Cross-agglutination relationships. J. Bact. 53, 509.

Fabian, F. W. \& Johnson, F. A. (1938). Experimental work on cucumber fermentation. X. Zymological studies of the cause of soft cucumbers. Tech. Bull. no. 157. Agric. Exp. Sta., Mich. State College.

JACoBelli, G. (1953). Utilization de milieux de culture gélifiés par des substances pectiques. C.R. Acad. Sci., Paris, 236, 228.

JERmYN, M. A. \& Tomkins, R. G. (1950). The chromatographic examination of the products of the action of pectinase on pectin. Biochem. $J .47,437$.

JonEs, D. R. (1946). A medium for investigating the breakdown of pectin by bacteria. Nature, Lond. 158, 625.

Jones, G. E. (1956). A study of the pectolytic bacterial population in some farm water supplies. J. appl. Bact. 19, 231.

Kertesz, Z. I. (1951). The Pectic Substances. New York: Interscience Publishers, Inc.

Kraght, A. J. \& Starr, M. P. (1953). Pectic enzymes of Erwinia carotovora. Arch. Biochem. Biophys. 42, 271.

Luh, B. S. \& Phaff, H. J. (1951). Studies on polygalacturonase of certain yeasts. Arch. Biochem. Biophys. 33, 212.

McCready, R. M., Owens, H. S. \& Maclay, W. D. (1943). The use of fibrous sodium pectate as a substitute for agar in bacteriological gels. Science, 97, 428 .

Mruls, G. B. (1949). A biochemical study of Pseudomonas prunicola Wormald. 1. Pectin esterase. Biochem. J. 44, 302.

Nortue, B. K. \& VAUghn, R. H. (1953). The pectolytic activity of species of Bacillus. Food Res. 18, 57.

Oxford, A. E. (1944). Production of a soluble pectinase in a simple medium by certain plant-pathogenic bacteria belonging to the genus Pseudomonas. Nature, Lond. 154, 271.

Ozawa, J. (1947). Fermentation of pectin. I. Conditions under which protopectinase is active. Nogaku Kenkyū, 37, 14. From Chem. Abstr. 44, 5942, 1950.

Ozawa, J. (1951). Studies on the pectic enzymes. I. Action of pectinase. Ber. Ohara Inst. 9, 431. Through Chem. Abstr. 46, 9132, 1952.

Report (1956). Coli-aerogenes (1956) Sub-committee of the Society for Applied Bacteriology. J. appl. Bact. 19, 108.

Roboz, E., Barratt, R. W. \& TAtum, E. L. (1952). Breakdown of pectic substances by a new enzyme from Neurospora. J. biol. Chem. 195, 459.

SABet, K. A. \& Dowson, W. J. (1951). Action of phytopathogenic bacteria on pectate gel. Nature, Lond. 168, 605.

Schubert, E. (1954). Einfluss von Wasserstoff- und Alkali-Ionen auf den enzymatischen Abbau von Pektin verschiedenen Veresterungsgrades durch Pektinglykosidasen und Pektinglykosidasegemische. Helv. chim. acta, 37, 691.

Sefgmiller, C. G. \& Jansen, E. F. (1952). Polymethylgalacturonase, an enzyme causing the glycosidic hydrolysis of esterified pectic substances. J. biol. Chem. $195,327$. 
Shishelova, N. A. (1951). Formation of protopectinase by phytopathogens. Microbiology, Moscore, 20, 430.

Sмrтн, W. K. (1958). Chromatographic examination of the products of digestion of pectic materials by culture solutions of plant pathogenic and other bacteria. J. gen. Microbiol. 18, 42.

Stuart, C. A., Baker, M., Zimmerman, A., Brown, C. \& Stone, C. M. (1940). Antigenic relationships of the coliform bacteria. J. Bact. 40, 101.

Stuart, C. A., Griffin, A. M. \& Baker, M. E. (1938). Relationships of coliform organisms. J. Bact. 36, 391.

TAxlor, C. B. (1951). The soft-rot bacteria of the coli aerogenes group. Proc. Soc. appl. Bact. 14, 95.

Wieringa, K. T. (1949). A method of isolating and counting pectolytic microbes. Proc. 4th Congr. int. Microbiol. 4, 482.

Woon, R. K. S. (1951). Pectic enzymes produced by Bacterium aroideae. Nature, Lond. 167, 771.

Woov, R. K. S. (1955). Studies in the physiology of parasitism. XVIII. Pectic enzymes secreted by Bacterium aroideae. Ann. Bot., Lond. 19, 1.

(Received 27 May 1957) 